who said that if a black panther could talk, he would talk like Bagheera?

But I mustn't quibble. It's a lovely collection; we shall all find gaps in it; we shall hope all the more for a companion volume soon.

JOHN MOORE

\title{
The Original Water-colour Paintings by John James Audubon for "The Birds of America". 2 vols. Michael Joseph, 25 gns.
}

Virtually the entire series of John James Audubon's unequalled paintings is reproduced in 431 plates in full colour with the accuracy and detail made possible by modern photographic techniques. A black and white reproduction of one plate, the California condor, is reproduced on Plate 16 opposite, by kind permission of the publishers.

Audubon was a pioneer of realism in the depiction of wildlife, and especially birds, and, as so rarely happens, the pioneer turned out to be a genius who has often been copied but never surpassed, or even equalled. We in Britain can be proud that when this great man was finding it hard to achieve recognition in his homeland, it was a visit to Britain and the helping hand of such far-sighted Englishmen as William Roscoe and the Rathbones of Liverpool who set him on the high road to material as well as artistic success.

I commend these two volumes to anybody wishing to make a very special gift to any ornithologist or bird-lover. It would be a splendidly appropriate retiring present, for instance, for someone who had given years of voluntary service in the natural history movement.

RICHARD FITTER

\section{Men and Pandas, by Ramona and Desmond Morris. Hutchinson, 50s.}

Some popular animals, like horses and dogs, have had a long courtship period with mankind, allowing time to gain acceptance, but the speed with which the giant panda has captured the affection of man has, by comparison, been a shot-gun wedding. Less than a century ago in 1869 , the intrepid missionary, Abbé Armand David discovered the giant panda and revealed it to western society, which had to wait a further 70 years to see a live one. The privilege went to Ruth Harkness, who stepped ashore in San Francisco on December 18th, 1936, with a $3 \mathrm{lb}$ cub, and, with the now familiar incredulous publicity which attends all panda transactions, started the Panda Epoch. It is perhaps hard to realise that to this date only seventeen individual giant pandas have been seen outside China, and yet our society is littered with the trinketry of the Panda Cult.

Ramona and Desmond Morris have now collated the whole intriguing story of these endearing animals in a book which not only covers the known biology of the species, but also traces the career of individual animals which have made headlines over the past thirty years, such as Su Lin, Ming and Chi Chi. As the circumstances surrounding the capture of the first giant pandas in the mid-thirties were mysterious, so is their relationship to other 